\title{
音環境に着目した保育施設の実態調査 \\ A FIELD STUDY OF NURSERY FACILITIES FOCUSING ON SOUND ENVIRONMENT
}

\author{
上野 佳奈子*1, 宮塚 健*2, 野口紗 生 $^{* 3}$, 船場 ひさお*4, 倉斗 綾子*5 \\ Kanako UENO, Ken MIYATSUKA, Saki NOGUCHI, \\ Hisao FUNABA and Ryoko KURAKAZU
}

\begin{abstract}
This study aims to investigate the current situation of acoustical environment of nursery facilities via a field survey conducted at twelve nursery facilities. In the survey, the division of spaces of each age, dimensions and finishes of rooms, and children's activities were observed. Moreover,the background and characteristics of each facility, users' evaluation of facilities, and evaluation on the acoustical environment in nursery rooms were investigated. Additionally, noise level and reverberation time were measured in four facilities and management method to maintain comfortable sound environment were observed in one facility. On the basis of the results, the requirements for improving the acoustical environment of nursery rooms were considered.
\end{abstract}

\section{Keywords : Nursery F acilities, Sound environment, Room environment, F ield survey 保育園，音環境，室内環境，実態調査}

\section{1. はじめに}

現在、女性の社会進出や労働環境の変化などに伴う保育ニーズの 高まりを受け、各地に保育施設が増設されている。保育室は、乳幼 巟が生活の場として長時間を過ごす空間であり、聴力・言語能力・ 心身の発育や知識の獲得のための環境、午睡・食事などの生活行為 を支えるための環境としての整備が求められる。音声言語の獲得の 面では、乳児期は母語獲得に必要な言語音知覚の基礎を獲得してい く時期、幼児期は言語の音素体系に基づいた音の知覚と生成を徐々 に完成させていく時期であり、雑音・残響環境の影響を受けや寸い と言われている 1)。また、乳幼児期は周囲の環境音の中から必要と する音響情報を抽出してそれを理解していく聴覚スキルも未熟な段 階にあり 2)、海外では「乳幼児期の子どもは可能な限り最高の音響 条件を必要としている」という認識のもとに音響性能の基準が示さ れている例もある ${ }^{3)}$ 。睡眠時の騒音による睡眠の質の低下は、子ど もの能力の発達や免疫力に影響するとの報告 ${ }^{4)}$ ある。しかしなが ら、保育園の設計・運用においては音環境保全の必要性が一般に認 識されておらず、喧騒感が非常に高い状況があることが、国内外の

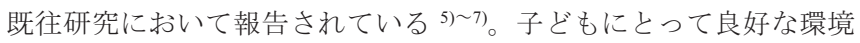
はおろか、聴覚保護を目的とした労働環境の許容限度に迫る騒音環 境でもあることが指摘されており ${ }^{3)}$ 、保育室の音環境保全は重要な 課題となっている。

*1 明治大学理工学部建築学科 教授・博士 (工学)

*2 明治大学大学院理工学研究科建築学専攻 大学院生

*3 明治大学研究知財戦略機構 研究推進員 - 博士 (国際情報通信学)

*4 岩手大学 COC 推進室 特任准教授. 博士 (芸術工学)

*5 千葉工業大学創造工学部デザイン科学科准教授・博士(工学)
子どもが日常を過ごす施設の音環境については、日本建築学会か ら 2008 年に「学校施設の音環境保全規準・設計指針」 ${ }^{8)}$ が発行され た。この規準では、小・中・高等学校の施設を対象に、音環境保全 のための推奨条件及びその設計手法がまとめられている。一方、未 就学児童のための保育・教育施設については、上記規準の対象には 含まれておらず、現在この規準をより低年齢の子どもたちの施設へ 拡充するための取組が行われている。この取組において、保育施設 の実情を踏まえた規準・指針を示すために、音環境に関わる保育施 設の実態を把握することが必要とされている。既往の研究としては、 吉澤ら ${ }^{9}$ は昭和 40 年代前後に設立された 8 か所の保育園で音環境に 着目した実態調査を行い、保育室間は隣室と空間的に繋がりをもつ 隔壁構造が多いこと、午睡時に異なる年齢の活動による騷音影響を 受けうる現状があることを指摘した。これらは、学校施設とは異な る保育施設特有の音響性能指針のあり方に重要な示唆を与えている。 しかしながら、この研究の調查対象は建設年が 40 50 年ほど前の施 設であることから、近年設置者や設置形態が多様化している保育施 設について、同様の視点での状況把握が求められている。

そこで本研究では、過去 10 年余りに建設された様々な特徵をもつ 保育施設の音環境の現状及び建築音響性能面の課題を把握すること を目的に、12 か所の保育施設において実態調查を行った。 
表 1 調査対象の特徵

\begin{tabular}{|c|c|c|c|c|c|c|c|c|c|c|}
\hline \multirow{3}{*}{$\begin{array}{l}\text { 対 } \\
\text { 象 } \\
\text { 園 }\end{array}$} & \multicolumn{4}{|c|}{ 概要 } & \multicolumn{2}{|l|}{ 建築 } & \multicolumn{3}{|c|}{ 人数 } & \multirow{3}{*}{ 施設の特徴 } \\
\hline & \multirow{2}{*}{\begin{tabular}{|l|} 
設置 \\
主体 \\
$($ 運営) \\
\end{tabular}} & \multirow{2}{*}{$\begin{array}{l}\text { 施設 } \\
\text { 種別 }\end{array}$} & \multirow[b]{2}{*}{ 沿革 } & \multirow[b]{2}{*}{ 地域 } & \multirow{2}{*}{ 構造/立地 } & \multirow{2}{*}{$\begin{array}{l}\text { 床 } \\
\text { 面積 } \\
{\left[\mathrm{m}^{2}\right]}\end{array}$} & \multirow{2}{*}{$\begin{array}{l}\text { 保育者数 } \\
\text { (職員数) } \\
\text { [名] }\end{array}$} & \multicolumn{2}{|c|}{ 園児数 [人] } & \\
\hline & & & & & & & & 全体 & 内訳 & \\
\hline A & \begin{tabular}{|l|} 
一般 \\
財団 \\
法人 \\
\end{tabular} & 認可 & $\begin{array}{l}2011 \text { 法人設立 } \\
2012 \text { 保育園開設 }\end{array}$ & $\begin{array}{c}\text { 神奈川県 } \\
\text { 横浜 }\end{array}$ & $\begin{array}{c}\text { RC造 } \\
\text { 駅ビルの3階/ } \\
\text { 高速道路付近 } \\
\end{array}$ & 464 & $16(37)$ & 104 & \begin{tabular}{|ll}
$(0) 10$ & $(1) 18$ \\
$(2) 20$ & $(3) 20$ \\
$(4) 20$ & $(5) 16$ \\
\end{tabular} & $\begin{array}{l}\text { 保育室としての利用を想定せずに } \\
\text { 建てられた駅ビルの貨を使用. ワ } \\
\text { シルーム型保育室. }\end{array}$ \\
\hline B & $\begin{array}{l}\text { 社会 } \\
\text { 福祉 } \\
\text { 法人 }\end{array}$ & 認可 & $\begin{array}{l}1959 \text { 法人設立 } \\
2012 \text { 保育園開設 }\end{array}$ & $\begin{array}{l}\text { 神奈川県 } \\
\text { 相模原市 }\end{array}$ & $\begin{array}{l}\text { 木造平屋建て/ } \\
\text { 住宅地 } \\
\text { 県道に面する }\end{array}$ & 629 & $11(28)$ & 60 & $\begin{array}{ll}\text { (0) } 10 & (1) 12 \\
(2) 12 & (3) 15 \\
(4) 15 & (5) 12\end{array}$ & $\begin{array}{l}\text { 建築家により設計された木造平屋 } \\
\text { 建ての保育園. }\end{array}$ \\
\hline $\mathrm{C}$ & \begin{tabular}{|l} 
企業 \\
(大学) \\
\end{tabular} & \begin{tabular}{|c|} 
東京都 \\
認証
\end{tabular} & 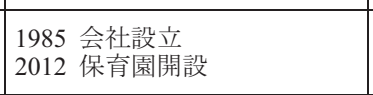 & $\begin{array}{l}\text { 東京都 } \\
\text { 新宿区 }\end{array}$ & $\begin{array}{c}\mathrm{RC} \text { 造 } \\
4 \text { 階建の2階/ } \\
\text { 大学敷地内 }\end{array}$ & 360 & $12(16)$ & 60 & $\begin{array}{ll}(0) 9 & (1) 15 \\
(2) 12 & (3) 12 \\
(4) 12 & (4) 12 \\
\end{array}$ & 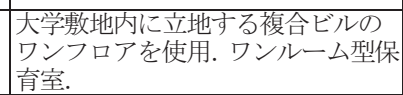 \\
\hline $\mathrm{D}$ & 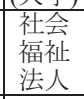 & 認可 & $\begin{array}{l}2002 \text { 保育方法等を学ぶ会を主 } \\
\text { 催 } \\
2007 \text { 保育園開設 }\end{array}$ & $\begin{array}{l}\text { 東京都 } \\
\text { 新宿区 }\end{array}$ & $\begin{array}{c}\text { RC造 } \\
\text { B1階 4階建て/ } \\
\text { 住宅地 } \\
\end{array}$ & 1558 & $26(41)$ & 115 & $\begin{array}{|ll|}(0) 15 & (1) 20 \\
(2) 20 & (3) 20 \\
(4) 20 & (5) 20 \\
\end{array}$ & $\begin{array}{l}\text { 保育に対する明確な理念を持つ園 } \\
\text { 長が自ら施設作りを主導. }\end{array}$ \\
\hline E & $\begin{array}{l}\text { 社会 } \\
\text { 福祉 } \\
\text { 法人 }\end{array}$ & 認可 & $\begin{array}{l}1974 \text { 保育園開設 } \\
1998 \text { 全体改築 } \\
2011 \text { 新園含竣工 }\end{array}$ & $\begin{array}{l}\text { 東京都 } \\
\text { 多摩市 }\end{array}$ & \begin{tabular}{|c|c|} 
RC造 \\
木造,鉄骨部有 \\
2階建て/住宅地
\end{tabular} & 984 & $18(23)$ & 127 & $\begin{array}{ll}(0) 9 & (1) 19 \\
(2) 24 & (3) 25 \\
(4) 25 & (5) 25\end{array}$ & $\begin{array}{l}\text { 「混じり合う」をコンセプトに建築 } \\
\text { 家により設計された. 意匠的な開口 } \\
\text { 部・吹抜けによる連続性の高い空間 } \\
\text { が特徵. }\end{array}$ \\
\hline $\mathrm{F}$ & $\begin{array}{l}\text { 一般 } \\
\text { 企業 }\end{array}$ & \begin{tabular}{|c|} 
東京都 \\
認証
\end{tabular} & $\begin{array}{l}2000 \text { 系列鉄道会社にて保育事 } \\
\text { 業開始 } \\
2005 \text { 保育園開設 } \\
2006 \text { 株式会社設立 } \\
\end{array}$ & \begin{tabular}{|l} 
東京都 \\
世田谷区
\end{tabular} & $\begin{array}{l}\text { 軽量鉄骨造/ } \\
\text { 鉄道高架下 }\end{array}$ & 306 & $10(25)$ & 39 & $\begin{array}{ll}(0) 11 & (1) 12 \\
(2) 12 & (3) 3 \\
(4) 0 & (5) 1\end{array}$ & $\begin{array}{l}\text { 鉄道系列会社の保育事業が開設・運 } \\
\text { 営する高下に立地する保育園. }\end{array}$ \\
\hline G & $\begin{array}{l}\text { 一般 } \\
\text { 企業 }\end{array}$ & \begin{tabular}{|l|l} 
川崎市 \\
認定
\end{tabular} & \begin{tabular}{|l|}
2011 保育園開設（無認可保育 \\
園と乙て) \\
2014 川崎市認定保育園
\end{tabular} & \begin{tabular}{|l} 
神奈川県 \\
川崎市
\end{tabular} & $\begin{array}{l}\text { 鉄骨造 } \\
\text { 3階建の1階/ } \\
\text { 住宅地 }\end{array}$ & 93 & $8(16)$ & 30 & $\begin{array}{ll}(0) 4 & (1) 17 \\
(2) 5 & (3,4) 2 \\
(4) 0 & (5) 2\end{array}$ & $\begin{array}{l}\text { テナントビルのワンフロア (元は貸 } \\
\text { 事務所) を保育園に改装. ワンル } \\
\text { ム型保育室. }\end{array}$ \\
\hline $\mathrm{H}$ & $\begin{array}{l}\text { 社会 } \\
\text { 福祉 } \\
\text { 法人 }\end{array}$ & 認可 & $\begin{array}{l}2012 \text { 公立園の建替に伴い民設 } \\
\text { 民営保育園として新築・・開設 }\end{array}$ & $\begin{array}{c}\text { 神奈川県 } \\
\text { 川崎市 }\end{array}$ & $\begin{array}{c}\text { 鉄骨造2階建て/ } \\
\text { 住宅地 }\end{array}$ & 1120 & $\begin{array}{l}\text { 21(29+補助 } \\
\text { パート) }\end{array}$ & 130 & $\begin{array}{ll}(0) 10 & (1) 22 \\
(2) 25 & (3) 26 \\
(4) 26 & (5) 21\end{array}$ & $\begin{array}{l}\text { 川崎市で公立園園長を長く勤めた } \\
\text { 園長の要望 (理想の保園)をもと } \\
\text { に設計された施設. }\end{array}$ \\
\hline I & $\begin{array}{l}\text { 学校 } \\
\text { 法人 }\end{array}$ & 認定こ & \begin{tabular}{|l|}
1970 法人・幼稚園設立 \\
2001 幼稚園新園舎竣工 \\
2012 認定こども園・保育園開 \\
設
\end{tabular} & $\begin{array}{l}\text { 埼玉県 } \\
\text { 久喜市 }\end{array}$ & \begin{tabular}{|c|} 
保: 木造平屋建て \\
(一部2階) \\
幼: 鉄骨造平屋建 \\
て/住宅地 \\
\end{tabular} & $\begin{array}{l}\text { 保: } \\
496 \\
\text { 幼: } \\
1352 \\
\end{array}$ & $34(48)$ & \begin{tabular}{|l|} 
保: \\
34 \\
幼: \\
205 \\
\end{tabular} & $\begin{array}{ll}(0) 6 & (1) 14 \\
(2) 14 & (3) 65 \\
(4) 70 & (5) 70\end{array}$ & 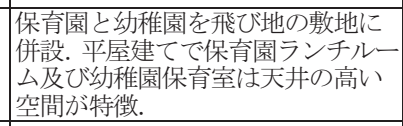 \\
\hline $\mathrm{J}$ & $\begin{array}{l}\text { 一般 } \\
\text { 企業 }\end{array}$ & 認可 & $\begin{array}{l}2000 \text { 保育事業開始（系列園開 } \\
\text { 設） } \\
2013 \text { 保育園開設 }\end{array}$ & \begin{tabular}{|l} 
神奈川県 \\
横浜市
\end{tabular} & $\begin{array}{c}\text { 鉄骨造/ } \\
\text { 鉄道高架下 }\end{array}$ & 386 & $20(26)$ & 56 & $\begin{array}{ll}(0) 6 & (1) 10 \\
(2) 11 & (3) 11 \\
(4) 11 & (5) 7\end{array}$ & $\begin{array}{l}\text { 鉄道系列会社の保育事業部による } \\
\text { 高喿下に立地する保育園. }\end{array}$ \\
\hline K & $\begin{array}{l}\text { 社会 } \\
\text { 福祉 } \\
\text { 法人 }\end{array}$ & 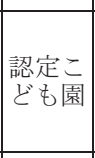 & \begin{tabular}{|l|}
1971 認可外保育園開園 \\
1974 幼稚園開園 \\
2001 幼保一体型新園舎竣工 \\
2008 幼保連携型・認定こども \\
園開設
\end{tabular} & $\begin{array}{c}\text { 埼玉県 } \\
\text { 北葛飾郡 }\end{array}$ & $\begin{array}{c}\text { 木造平屋建て/ } \\
\text { 住宅地 }\end{array}$ & 1187 & $20(30)$ & 164 & $\begin{array}{ll}(0) 3 & (1) 9 \\
(2) 14 & (3) 38 \\
(4) 46 & (5) 54\end{array}$ & 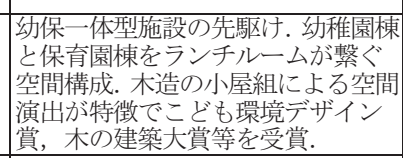 \\
\hline $\mathrm{L}$ & $\begin{array}{l}\text { 一般 } \\
\text { 企業 }\end{array}$ & 認可 & $\begin{array}{l}1994 \text { 保育事業開始 } \\
2008 \text { 保育園開設 }\end{array}$ & $\begin{array}{l}\text { 東京都 } \\
\text { 練馬区 }\end{array}$ & $\begin{array}{c}\text { RC造 } \\
\text { 4階建の1階/ } \\
\text { 住宅地 }\end{array}$ & 426 & $10(16)$ & 66 & $\begin{array}{ll}(0) 6 & (1) 10 \\
(2) 12 & (3) 12 \\
(4) 13 & (5) 13\end{array}$ & $\begin{array}{l}\text { 介護付有料老人ホームとの複合施 } \\
\text { 設. }\end{array}$ \\
\hline
\end{tabular}

\section{2. 調査の概要}

2005 年から 2013 年にかけて開設した 12 か所の保育施設 (表 1) を実態調査の対象とした。立地条件や規模、設置者、運営の仕方に よって、音環境の状況も異なるものと考え、これらの面で多様な施 設の特徴を把握することを目指して、対象施設を選定した。A・B・ $\mathrm{D} \cdot \mathrm{E} \cdot \mathrm{H} \cdot \mathrm{I} \cdot \mathrm{J} \cdot \mathrm{K} \cdot \mathrm{L}$ 園は認可、 $\mathrm{C} \cdot \mathrm{F}$ 園は東京都認証、 $\mathrm{G}$ 園は川 崎市認定の保育園、 I ・ K は認定こども園である ${ }^{10)}$ 。 A ・ C ・ G 園は テナントビルの一画を使用しており、うち $\mathrm{A} \cdot \mathrm{G}$ 園は保育室として の利用を想定されずに建設されたビルの一室である。 B・E・K・I 園は建築家の設計による施設であり、K 園は学会等から複数の賞を 受賞している。 $\mathrm{D} ・ \mathrm{H}$ 園は園長の保育環境に対する理念が反映され た施設であるが、両者の空間構成は異なる特徵をもっている。 F・J 園は、鉄道会社の保育事業が開設・運営する鉄道高架下の保育園で ある。L 園は介護付有料老人ホームとの複合施設で、 4 階建ての 1 階の 一部に保育園が設置されている。

調查内容としては、通常保育日に保育施設を訪問し、以下の調查 を行った。

- 施設の特色に関する資料収集 : 沿革 ・規模 - 運営上の特徵・園 児数・職員数・施設概要の把握
- 施設 /保育見学 : 建築的特徵・室内の仕上げ材料・空間や異年 齢の区切り方の把握, 保育 - 児童の様子・音環境面の特徵の観 察

・代表者に対するインタビュー：保育目標・運営上の工夫、施設 や音環境に関する意見について聴取

調查は 2013 年 5 月から 2015 年 9 月の通常保育日（2 時間程度） に、代表者へのインタビューも含めて行った。加えて、音環境の観 点で特徴がみられた $\mathrm{A} \cdot \mathrm{B} ・ \mathrm{I} \cdot \mathrm{K}$ 園では音環境の測定と活動内容の 調查、 $\mathrm{A} \cdot \mathrm{B} \cdot \mathrm{I} \cdot \mathrm{J}$ では残響時間の測定を行った。 $\mathrm{A} \cdot \mathrm{I}$ (保育園舎) ・ $\mathrm{K}$ 園は保育室が年齢ごとに仕切られておらず空間の連続性が高い、 $\mathrm{B} \cdot \mathrm{I} ・ \mathrm{~K}$ 園は天井高が高く吸音仕上げがない、という特徴をもち、 これらは音環境の面では不利な条件となっている。J 園は通常の天 井高で天井が吸音仕上げとなっており、残響時間の比較対象として 測定した。音環境の測定には、普通騒音計（RION, NL-21）及び IC レコーダ（OLYMPUS，LS20-M）を保育室内の棚の上等に設置して 録音し、後日分析した注 1 )。残響時間の測定には、折り紙インパル 又音源 ${ }^{11}$ 及び分析機能付き騒音計（RION, NA-28）を用いた。また、 音環境保全において特に有効な運用上の工夫が夕られた $\mathrm{K}$ 園につい ては、2 日間の観察調查を行った。 


\section{3. 調査結果}

\section{1 空間構成}

保育室の空間構成（仕切り方）について図 1、インタビューで聞 かれた意見を表 2 、特徵的な空間や設えを図 2 に示す。図 1 には、 年齢ごとのスペースの境界の有無と遮音性能の程度とともに、天井 高 $(\mathrm{CH})$ の情報を模式図として示した。図 1 に示寸とおり、すべて の年齢の保育室が独立した（遮音性能が確保された）室で構成され ていたのは H 園のみであり、その他は複数の年齢のスペースが連結 した空間構成となっていた。保育方法と空間構成の関係に着目寸る と、複数の年齢の子どもを合同で保育する “異年齢保育”の実施と空 間構成が対応している園と、対応がみられない園があった。異年齢 保育を実施している園では、0１歳児、3〜 歳児もしくは 3〜 歳 児を合同とする、時間外保育のみ合同と寸るなど、各園の考え方や 運用状況と対応して、合同で保育する年齢にさまざまなパターンが みられた。

保育方法と空間構成との対応が見られない典型的な状況は、テナ ントビルを利用した $\mathrm{A} \cdot \mathrm{C}$ 園であり、年齢ごとの活動を基本として、 高さ $1 \mathrm{~m}$ に満たない棚や柵によって仕切られたスペースを分割しな がら、連続した一体空間を使用していた（図 2 (a))。また、「混じり 合う」をコンセプトに建築家によって設計された E 園は、2 階建の 吹抜け空間 $(\mathrm{CH}=5700 \mathrm{~mm})$ であるランチコーナー・一時保育室・廊
保育室, $\|$ : 壁 ・ 床, | : 可動間仕切・引き違い戸, ! : カーテン, ロ:棚

\begin{tabular}{|c|c|c|c|c|c|c|}
\hline 園 年撂令 & 0 & 1 & 2 & 3 & 4 & 5 \\
\hline A & $\mathrm{CH}=2700$ & i & $\square$ & & п & 口 \\
\hline B & $\mathrm{CH}=3000$ & I & & & HE $3985 \sim 465$ & 斜め天井) \\
\hline $\mathrm{C}$ & $\mathrm{CH}=2750$ & & & & & \\
\hline D & $\mathrm{CH}=2730$ & & $\mathrm{CH}=3230$ & & ${ }^{\mathrm{CH}=2730}$ & 口 \\
\hline E & $\mathrm{CH}=2400$ & & & $\mathrm{CH}=3600$ & 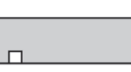 & $\mathrm{CH}=2850$ \\
\hline $\mathrm{F}$ & $\mathrm{CH}=2400$ & & & & & \\
\hline G & $\mathrm{CH}=2550$ & & & & & \\
\hline $\mathrm{H}$ & $\mathrm{CH}=2500$ & & & & & \\
\hline I & $\mathrm{CH}=2400$ & \begin{tabular}{|c|}
$\mathrm{CH}=3800$ \\
$\sim 6700$ \\
\end{tabular} & \begin{tabular}{|l} 
\\
$\mathrm{CH}=2400$ \\
\end{tabular} & & If & (曲面) \\
\hline $\mathrm{J}$ & $\mathrm{CH}=2450$ & ㅁ & & & & \\
\hline K & $\mathrm{CH}=2300 \sim$ & 4350 (斜め天 & & & $\mathrm{I}=2750 \sim 7550$ & (斜め天井) \\
\hline $\mathrm{L}$ & $\mathrm{CH}=2400$ & & & & & \\
\hline
\end{tabular}

図 1 年齢区分と保育室の間仕切り方（断面構成の模式図）注 2

表 2 インタビュー結果及び見学時の印象

\begin{tabular}{|c|c|c|}
\hline 園 & 空間・異年齢の区切り方に対する意見 & 音環境について \\
\hline A & $\begin{array}{l}\text { ·幼児は年齢ごとに行う活動があるたため区切れても良い. } \\
\text { •乳はやりた事や経験させたい゙区切れたら良い. }\end{array}$ & $\begin{array}{l}\text { ・空間が連続し隣の活動音が聞こえるる. } \\
\text { ·空を開けられす空調機を常時つけている. } \\
\text { *空調・機械換気音と活動音によりきわめて喧噪感が高い. }\end{array}$ \\
\hline B & $\begin{array}{l}\text { •活動に応じて引違い戸の開け閉めを行い，持っている力を伸ばすため } \\
\text { に異年齢と同年齢の活動を耐立する. }\end{array}$ & $\begin{array}{l}\text { ・あまり印象はない. } \\
\text { *保育室の天井高が高いため響きが長めではあるが, 支障は感じない, } \\
\text { 隣接する道路からの騒音が聞こえる. }\end{array}$ \\
\hline $\mathrm{C}$ & $\begin{array}{l}\text { •通常保育の時間は年齢毎の活動を行ゔが蔀屋が孤立していないので合える. }\end{array}$ & 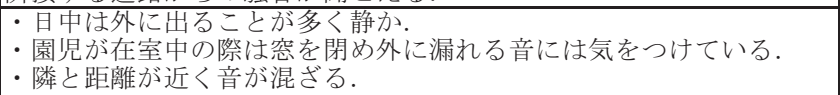 \\
\hline $\mathrm{D}$ & 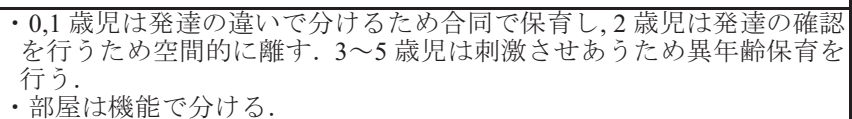 & $\begin{array}{l}\text { ・先生の大声ではなく,色々な音や余韻（木魚，太鼓，鈴）を合図に使 } \\
\text { 号調騒音が耳につく. }\end{array}$ \\
\hline $\mathrm{E}$ & 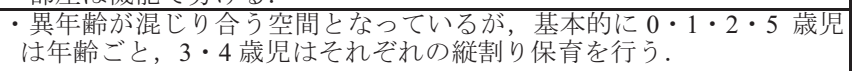 & ・天井高の高い一時保育室とランチコーナーが特に響く \\
\hline $\mathrm{F}$ & $\begin{array}{l}\text { ·基本的に各部屋(活動により2歳児は別行動)で保育を行う. } \\
\text { 室が区切られていて, 保育がやりやすい. }\end{array}$ & $\begin{array}{l}\text { ・電車の走行音,振動は特に気にならない. } \\
\text { 仕切りがあるので隣室からの音は気にならない. } \\
\text { *高架下ではあるが咸じない. }\end{array}$ \\
\hline G & 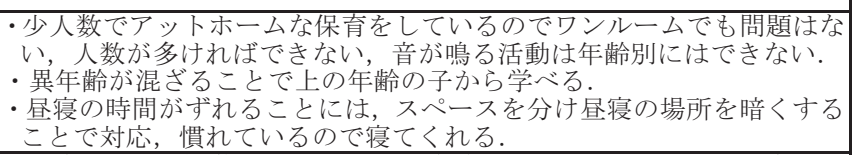 & 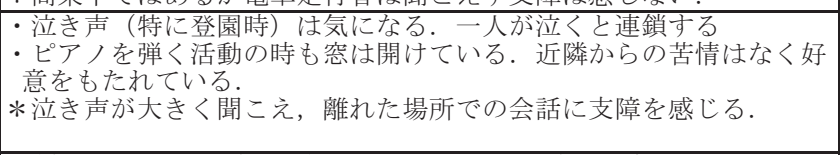 \\
\hline $\mathrm{H}$ & 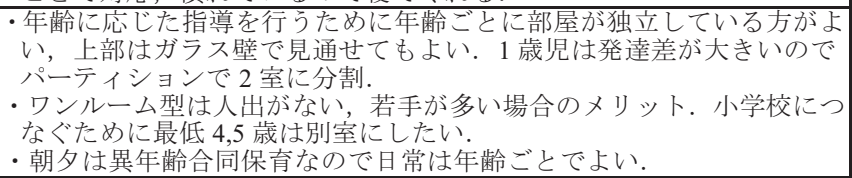 & 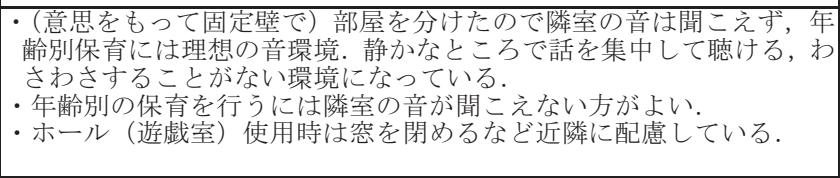 \\
\hline I & 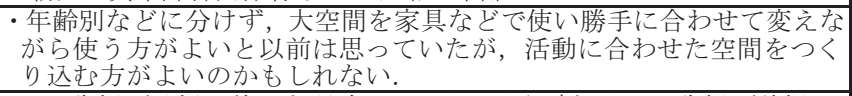 & 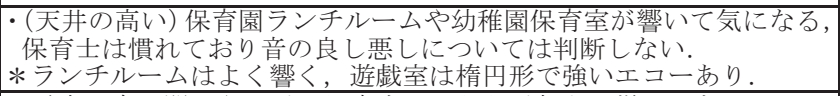 \\
\hline $\mathrm{J}$ & 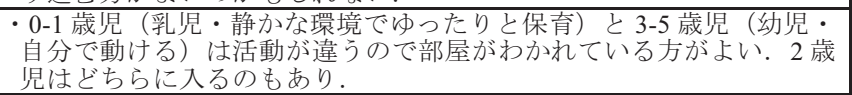 & 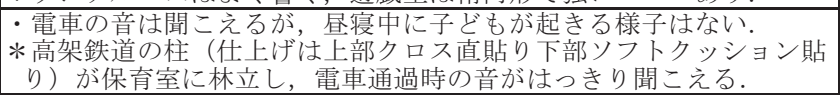 \\
\hline $\mathrm{K}$ & 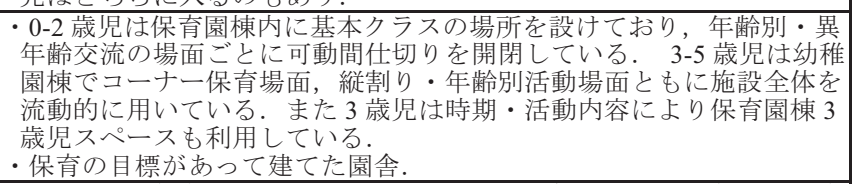 & 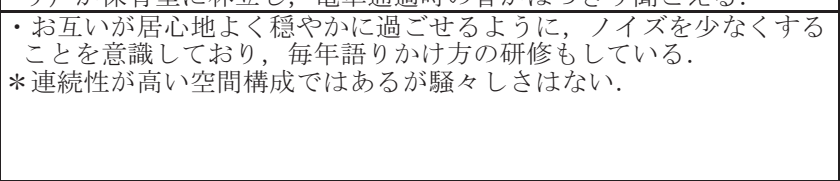 \\
\hline $\mathrm{L}$ & $\begin{array}{l}\text { ・0,1,2 は年齢ごとに独立していることで落ち着ける.3〜5歳は異年齢 } \\
\text { 保育のやりやさがあるので(仕切らず)一室でよい，ただし洛ち着 } \\
\text { きを得るために中央に棚を置いて仕切っている. }\end{array}$ & 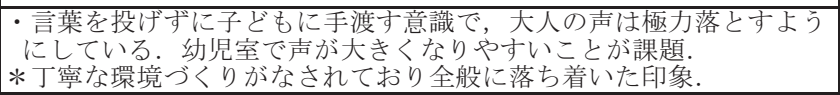 \\
\hline
\end{tabular}
インタビューで聞かれた意見，*：見学時の印象 


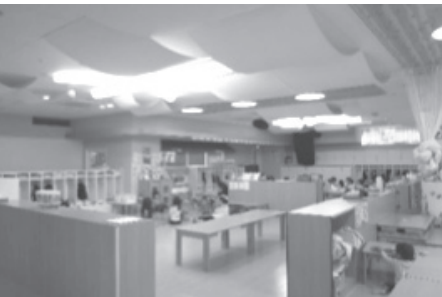

(a)ワンルーム型保育室（A 園）

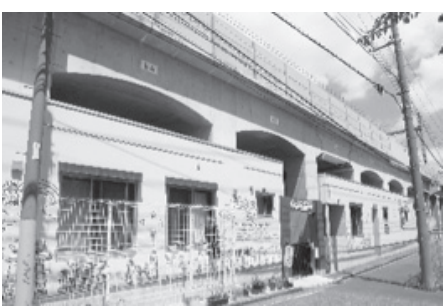

（c）高架鉄道下の保育園（J 園）

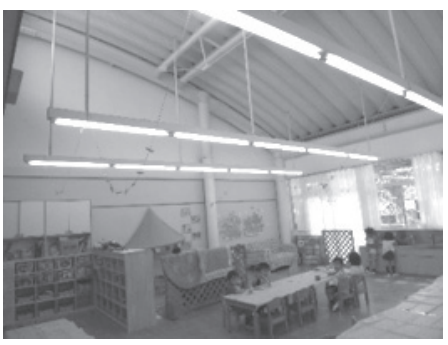

（d）天井の高い保育室（I 園・幼）

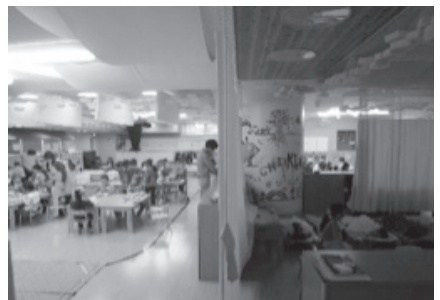

（b）ワンルーム型保育室・午睡時（A 園）

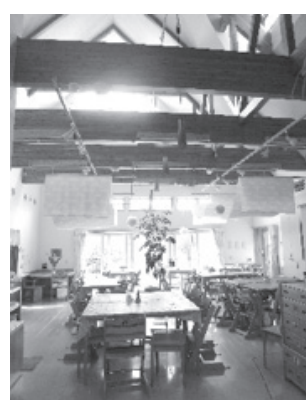

(e) 木造で天井の高い保育室（I 園・保

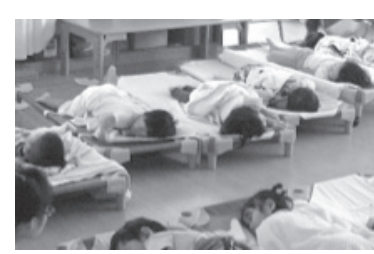

(f) 簡易ベッド

図 2 音環境面で特徵のある保育室, 設え

下を介して、0〜5 歳児室が空間的に連続しているが、異年齢保育は

3，4歳児のみでそれ以外は年齢ごとの保育を行っていた。

保育方法と空間構成との対応が見られた例として、B・I 園では年 齢別保育と異年齢合同保育の両方を行っており、これに対応する間 仕切りとして、B 園では異年齢保育を取り入れている $0 \sim 1$ 歳児室、 $3 \sim 5$ 歳児室で、各年齢の保育室間が建具（H=2200 mm の引違い戸、 上部ははめ殺し）により仕切られ、活動に応じて仕切り方を変えら れるように作られていた。同様に I 園（保育園部分）の 0 ２歳児室 も、各年齢の保育室が共用スペースを介して連結しており、保育室 と共用スペースの間には引違い戸が設置され状況に応じて開閉を使 い分けていた。また、異年齢保育をより積極的に行っている $\mathrm{D} \cdot \mathrm{K} \cdot$ $\mathrm{L}$ 園では、年齢ごとの保育室は設けず、複数の年齢用の保育室とし て一室を充てながら、あそびや活動に応じたスペース・仕切りを設 定している状況が見られた。D 園の 3〜5 歳児室は一室を使用してお り、「ブロックゾーン」「ごっこゾーン」「食事ゾーン」など活動内容 ごとに収納棚でスペースを仕切っていた。同様に K 園幼稚園棟の 3 $\sim 5$ 歳児室も「造形コーナー」「絵のコーナー」「英語コーナー」な ど活動に応じたスペースが設定され、一体空間が引違い戸（上部は 空間が連続）で仕切られていた。L 園の 3〜 歳児室も、一室内に活 動に応じたコーナーを設定し、一室の中央に棚を置き空間を分割し ていた。この他に、 $\mathrm{G}$ 園（全体で 30 名）・F 園の 3〜5 歳児（4 名） など少人数の場合に、異年齢を一室で保育しているケースがみられ た。

空間の連続性に関連する使用者側の意見としては、メリットとし て保育士同士が協力・連携しやすいこと、園児の活動を把握しやす
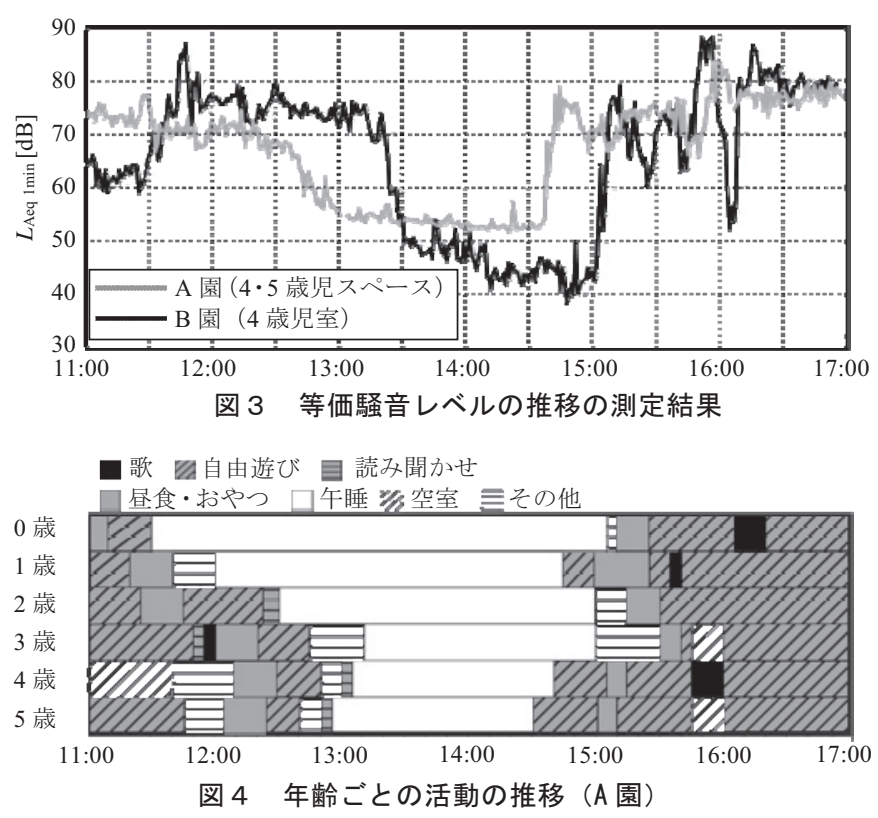

表 3 音環境の分析時間

\begin{tabular}{|l|l|l|}
\hline 活動 & 分析時間 & 備考 \\
\hline 午睡 & $10 \mathrm{~min}$. & 大半の児童が寝ている状態 \\
\hline 昼食 & $15 \mathrm{~min}$. & 食事時間中 \\
\hline 歌声 & $30 \sim 40 \mathrm{sec}$. & 子どもがピアノ伴奏に合わせて歌う声 \\
\hline リズムあそび & $4 \mathrm{~min}$. & CD 音楽, 音声, 手拍子, 足音が含まれる \\
\hline 読み聞かせ & $4 \sim 5 \mathrm{~min}$. & 保育士が絵本を読み聞かせる声 \\
\hline 自由あそび & $10 \sim 20 \mathrm{~min}$ & 㐫そび時間中の子どもの自由な発声 \\
\hline
\end{tabular}

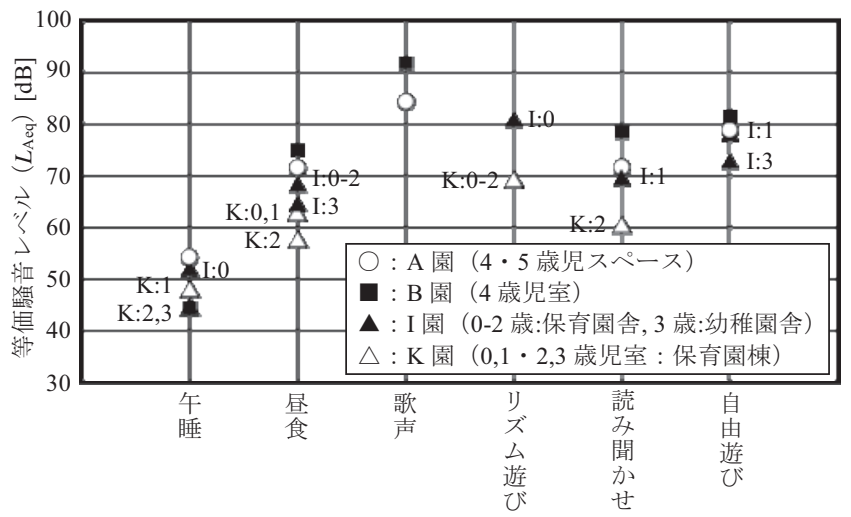

図 5 活動ごとの音環境 注3)

いこと、園児が他の年齢の様子を感じることで刺激を受けられるこ とが挙げられた。保育士同士の協力・連携は保育士が休憩をとる上 でも必要なことであり、特に、保育士の人数が少ない場合や若手保 育士が多い場合にワンルーム型はメリットが大きいとの話も聞かれ た。不満足な点の指摘においては、仕切られていないスペースで年 齢ごとの保育を行っている園で、他の年齢の活動音が聞こえる、意 識していないと音が混ざり散漫になる、といった音環境に関わるデ メリットが聞かれた。一方で、 $\mathrm{K}$ 園では一体空間で異なる活動を成 立させるための方法に積極的に取組んでいる様子も聞かれた（3.3 項に詳述)。各年齢の保育室が遮音性能を備えた壁で仕切られていた H 園は、園長の「年齢に応じた活動を重視しており、それを行うた めには年齢ごとに独立した部屋がある方がよい」という考えが背景 
となっていた。特に、「5 歳児の就学に向けた活動 (文字の学習など) は、別室で行いたい」という意見が $\mathrm{H}$ 園の他 $\mathrm{E}$ 園でも聞かれた。 $\mathrm{H}$ 園では、年齢ごとの部屋とは別に $3 \sim 5$ 歳児の保育室と同じ階にホー ル (遊戯室) が設けられており、異年齢合同の活動に使われていた。

\section{2 音環境}

$\mathrm{A} \cdot \mathrm{B} \cdot \mathrm{I} \cdot \mathrm{K}$ 園の保育室において、音環境の収録及び活動状況の 観察記録を行った。図 3 に A・B 園における等価騒音レベル $\left(\mathrm{L}_{\mathrm{Aeq}, 1 \mathrm{~min}}\right)$ の推移、図 4 に A 園における各年齢の活動内容の推移を示す。また、 表 3 に示寸音の発生状況からみて典型的な活動について、等価騒音 レベルを求めた結果を図 5 に示す。室内での活動時の騒音レベルは 「歌」80〜90 dB、それ以外の「昼食」「リズムあそび」「読み聞かせ」 「自由あそび」などの活動では 60-80 dB 前後で推移していた。「午 睡」時は 45〜 $55 \mathrm{~dB}$ であり、 $55 \mathrm{~dB}$ 程度と高めの值であった $\mathrm{A}$ 園で は、主な騒音源は空調騷音・機械換気音であり、敷地が高速道路に 面することと、駅ビルという建物の仕様により、終日空を開けるこ とはなく機械換気を常時作動している状況が確認された。また、A・ I 園では、午睡時にオルゴール音楽を鳴らしていた。図 4 に示すと おり、ワンルーム型の $\mathrm{A}$ 園の「午睡」時には年齢毎に入眠する時間 が異なり、3〜 5 歳児の「昼食・自由遊び」中に $0 \sim 2$ 歳児が「午睡」 を始めていた。午睡時は薄手のカーテンで異年齢スペース間の視環 境条件を仕切っていた（図 2 (b)）が、音を遮ることは期待できない。 低年齢から幼児までを一体空間で保育する場合には、幼児の活動に 伴う発生音が乳児の午睡に影響する可能性が懸念される。

鉄道高架下という立地が特徴的な $\mathrm{F} ・ \mathrm{~J}$ 園については、2つの園で かなり差がみられた。F 園では電車通過時の音はほぼ聞こえず、使 用者からも不満は聞かれなかった。一方、J 園（図 $2(\mathrm{c})$ ）では、高 架橋の柱が保育室に林立しており、電車の通過音がはっきりと確認 された。この差は、高架の建設年代や構造と関係しているとみられ る。午睡時には、床に直接薄いマット（厚さ数 $\mathrm{mm}$ ) を使用する園 もあり（表 4)、午睡という保育園特有の活動に対する床振動や騒音 の影響については、十分留意する必要がある。

保育室が積層していたのは、 $\mathrm{D} ・ \mathrm{E} ・ \mathrm{H}$ 園で、いずれも下階に低年 齢児（D：0-1 歳児， E : 0-4 歳児， $H ： 0 〜 2$ 歳児）を配置していた。 $\mathrm{H}$ 園ではこの理由について、「乳児は心身の発達が未熟であることか ら、健康な身体づくりが重要であり、日に 1,2 度は外遊びをするの で外に出しやすい 1 階の配置が望ましい、災害時緊急避難、待機場 所としても乳児室の 1 階配置が望ましい」との意見が聞かれた。比 較的動きが活発で午睡時間も短い幼児を上階に配置する例が多いこ とから、床衝撃音遮断性能の確保にも留意が必要とみられる。

室内の響きについて、仕上げ材料を表 4 に示す。吸音材が使われ ていない園が多く、吸音材の使用が見られたのは D・J 園（全般に 岩綿吸音板）、 $\mathrm{E}$ 園（午睡室の天井に $\mathrm{GW}$ ）、 $\mathrm{H}$ 園（遊戯室と廊下の み岩綿吸音板）であった。 $\mathrm{A} \cdot \mathrm{B} \cdot \mathrm{I} \cdot \mathrm{J}$ 園での残響時間測定結果（家 具や持ち物が置かれ人は居ない状態）を図 6 に示す。吸音材が使わ れていない場合、A（ワンルーム型，図 2 (a), $\mathrm{V}=648 \mathrm{~m}^{3}, \quad \bar{\alpha}=0.12$ 注4) $)$ B (4 歳児室, $\left.\mathrm{V}=133 \mathrm{~m}^{3}, \quad \bar{\alpha}=0.15\right) \cdot \mathrm{I}$ 園（3 歳児室，図 2 (d), $\left.\mathrm{V}=262 \mathrm{~m}^{3}, \quad \bar{\alpha}=0.15\right)$ の保育室では 1 秒程度であり、木造で開放感の 高い天井に特徴のある I 園ランチルーム (図 2 (e), V=752 m², $\bar{\alpha}=0.12$, 玄関ホールとの一体空間）では 1.4 秒という特に長めの残響時間で あった。一方、室内の天井に岩綿吸音板が使われていた J 園 $(2 \cdot 3$
表 4 保育室の室内仕上げと昼寝時に用いられる寝具

\begin{tabular}{|c|c|c|c|c|}
\hline \multirow{2}{*}{ 園 } & \multicolumn{3}{|c|}{ 室内表面仕上げ材料 } & \multirow{2}{*}{ 寝具（年齢） } \\
\hline & 床 & 壁 & 天井 & \\
\hline A & フローリング & 石膏ボード他 & 化粧石膏ボート & マット $(0 \sim 1)$ \\
\hline B & $\begin{array}{l}\text { 無垢フローリング } \\
\text { 量(0 2 歳児室) }\end{array}$ & $\begin{array}{l}\text { 石膏ボード } \\
\text { 杉板張り }\end{array}$ & $\begin{array}{l}\text { 石膏ボード } \\
+ \text { +土佐和紙 }\end{array}$ & 布団(0 5) \\
\hline $\mathrm{C}$ & $\begin{array}{l}\text { フローリング } \\
\text { カロペット }\end{array}$ & 石膏ボード & 石膏ボード他 & マット $(0 \sim 5)$ \\
\hline $\mathrm{D}$ & $\begin{array}{l}\text { リノリウム } \\
\text { 畕(0,1 歳児室) } \\
\text { カーヘヘット }\end{array}$ & 石膏ボード & 岩綿吸音板 & $\begin{array}{l}\text { ベビーベッド }(0) \\
\text { 布団 }(1,2) \\
\text { 簡易ベッド }(3 \sim 5)\end{array}$ \\
\hline E & 無垢フローリング & 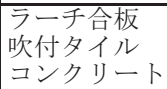 & $\begin{array}{l}\text { 吹付吸音 } \\
\text { 断熱材 } \\
\text { LVL(カラマッ) }\end{array}$ & ママット(0 5) \\
\hline $\mathrm{F}$ & 無垢フローリング & 石膏ボード & 石膏ボード & 布団 $(0 \sim 5)$ \\
\hline G & 塩化ビニルシート & 石膏ボード & 石膏ボード & $\begin{array}{l}\text { ベビーベッド }(0) \\
\text { マット }(0 \sim 5)\end{array}$ \\
\hline $\mathrm{H}$ & フローリング & 石膏ボード & 石膏ボード & $\begin{array}{l}\text { ベビーベッド(0) } \\
\text { 布団 }(1 \sim 5)\end{array}$ \\
\hline I & $\begin{array}{l}\text { フローリング } \\
\text { コルクタイル }\end{array}$ & 石膏ボード & 石膏ボード & 布団 $(0 \sim 3)$ \\
\hline $\mathrm{J}$ & フローリング & 石膏ボード & 岩綿吸音板 & $\begin{array}{l}\text { ベビーベッド }(0) \\
\text { 布団 }(1 \sim 5)\end{array}$ \\
\hline $\mathrm{K}$ & コルクタイル貼り & $\begin{array}{l}\text { ラスボード } \\
\text { モルタル塗 } \\
\text { 杉板張 } \\
\text { タイル張 }\end{array}$ & 珪酸かッウウ坂板 & $\begin{array}{l}\text { ベビーベッド }(0) \\
\text { 布団 }(1 \sim 3)\end{array}$ \\
\hline $\mathrm{L}$ & $\begin{array}{l}\text { フローリング } \\
\text { カーペット }\end{array}$ & 石膏ボード & 化粧石膏ボード & 簡易ベッド $(0 \sim 5$ \\
\hline
\end{tabular}

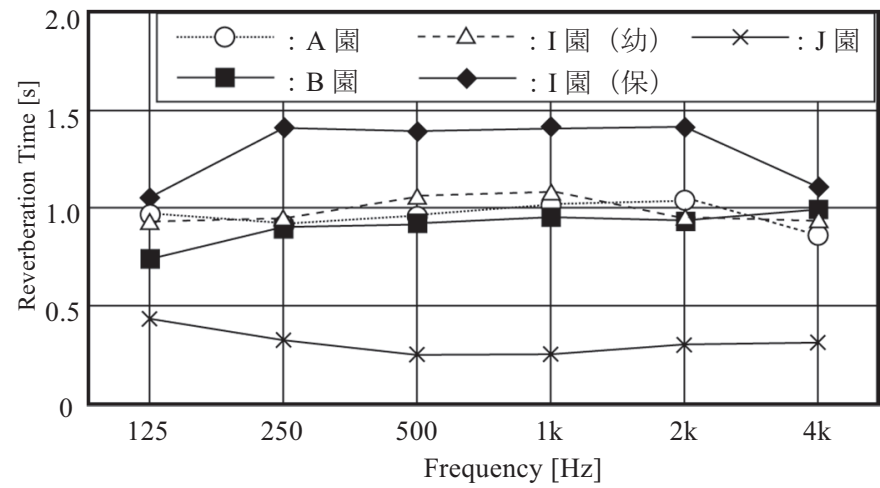

図 6 残響時間の測定結果

歳児室, $\left.\mathrm{V}=130 \mathrm{~m}^{3}, \bar{\alpha}=0.42\right)$ では、中高音域で $0.2 \sim 0.3$ 秒と非常に 短い残響時間となっていた。天井面の吸音に加えて、子どもの持ち 物、午睡用の布団（扉のない棚に収納）などによる吸音も寄与して いたとみられる。見学時の印象としては、天井が高いケース $(\mathrm{B} ・ \mathrm{E} ・$ I 園）、室の仕切りがなく床面積が広いケース（A 園）で、響きの長 さにより喧噪感が増している印象を受けた。特に I 園では、0〜2 歳 児が食事をするランチルーム（図 2 (e)）で「食器の音や泣き声が気 になる」とのことで、対策として薄い布を上部に吊り下げていた。 また、I 園は幼稚園の保育室（3～5 歳児室，図 2 (d)）でも響きが気 になるとのことで、「数年前までクラス単位での活動（一斎保育）が 主流だったときには気にならなかったが、一人一人の育ち・生活面 を大事にするようになってから音が気になってきた」との話が聞か れた。活動の仕方や目指寸保育によって、音環境の重要性が異なる ものとみられる。

\section{3 運用面のエ夫}

保育施設の音環境保全においては、建築的に性能を確保すると同 時に、良好な音環境を維持するための運用上の工夫も重要な役割を 果たすと考えられる。以下、落ち着いた環境づくりや音環境の向上 
につながる運用上の工夫について示す。

$\mathrm{K}$ 園では、子ども、大人とも居心地のよい穏やかな環境づくりを 目指して、“ノイズからの脱却”を掲げ、落ち着いた音環境づくりに 取り組んでいた ${ }^{12)}$ 。具体的には、保育者の丁寧な声がけを重要視し て、年に一度、保育者は外部講師のカウンセリング講習を受けてい るとのことであった。本調查に引き続き観察調查を行ったところ、 落ち着いた保育環境を維持するための保育者の対応として、以下が 確認された ${ }^{13)}$ 。

・朝夕の打合せにより活動の流れを共有し、クラスの活動が互い に妨害しあわないよう保育者間で綿密な連携をはかるなど、活動 に伴う音に対して十分に配慮する

・泣いている子どもには個別に速やかに応じ、状況により室外に 出るなど、子どもの欲求を汲夕取るとともに集団に配慮して対応 する

・ゲームなど賑やかになりやすい場面でも、保育者は適切な声の 大きさ、穏やかに語りかけるような声掛けを徹底し、落ち着く時 間を挟むなど子どもが興奮しすぎないように調整する

$\mathrm{K}$ 園の保育園棟 $0 \sim 3$ 歳児室は連続した一体空間で、 0,1 歳児室と 2,3 歳児室を可動間仕切り、2,3 歳児スペースの間を棚で区切って使 用している。年齢ごとの活動場面では一体空間内で異なる活動が行 われる時間帯もみられるが、終始落ち着いた音環境亡なっていた。 具体例として、図 7 に 0,1 歳児室と 2,3 歳児室の間の可動間仕切り を開け、異なる活動を並行して行っていた際の様子を示す。0-2 歳 児は合同で歌・踊りをおこなっており、3 歳児は静かに保育者の話 を聞いていた。どちらの保育者とも大きな声は出しておらず、むし ろささやくような声の出し方で園児に話しかけていた。歌う時には 大声ではなく適切な大きさでの歌い方を保育者が示し、踊りの時は 園児同士のスペースにゆとりをもたせ落ち着いて踊れる環境を整え る、といった工夫がみられた。連続した空間で異なる活動が行われ、 それぞれが発声音をともなう活動であっても妨害し合わずに双方の 活動が進められており、これには普段からの保育者の細やかな声が け、保育者自身の発声の仕方の工夫、ゆとりをもたせた環境設定と いう、保育者の働きかけによる効果が大きいと推察される。図 5 に おいては、年齢や活動の差もあり直接比較することはできないもの の、他の園よりも 10〜20 dB 低めの騒音レベルが確認された。なお、 $\mathrm{K}$ 園の保育室は一体空間型で天井は高め、吸音材料も使用されてい ないため、遮音・響きの両方の観点で物理的な環境としては不利な 条件であり、比較的静かな騒音レベルが確認されたことには、運用 面の寄与が大きいものと考えられる。

このような音環境保全を意識した保育実践方法については、I 園 においても「言葉を手渡す」「大人は声を極力落とす」という類似の 意識による実践が確認された。しかしながら、一般には共有されて いないものとみられ、今後その手法や重要性を広めることが、落ち 着きのある音環境を維持するという観点で有効と考えられる。

\section{4. 保育施設の音環境保全に向けた考察}

以上の調査結果に基づき、保育室で確保すべき建築音響性能につ いて考察する。

\section{1 室内騒音}

保育室では、言語や聴覚の発達段階にある乳幼児の音声聴取に求

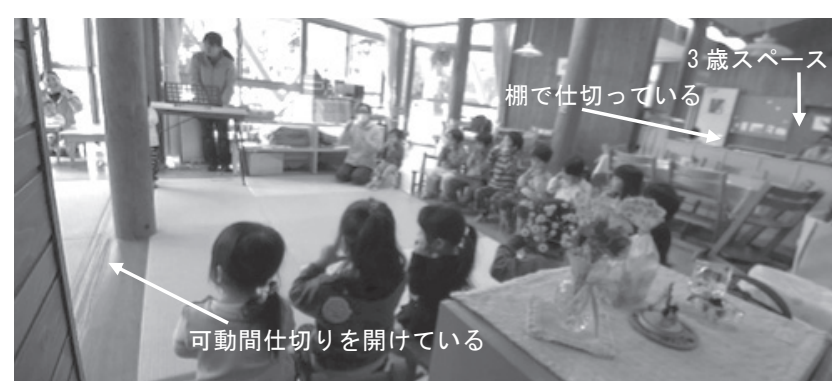

（a）可動間仕切りを開けて 0-2 歳児合同で歌う様子

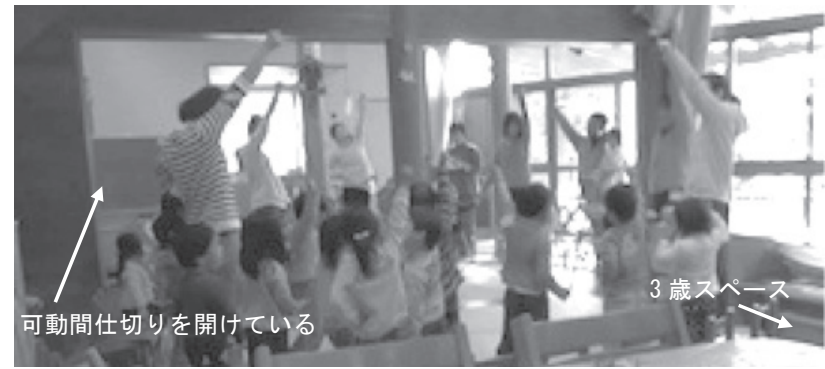

(b) 可動間仕切りを開けて 0-2 歳児合同で踊る様子

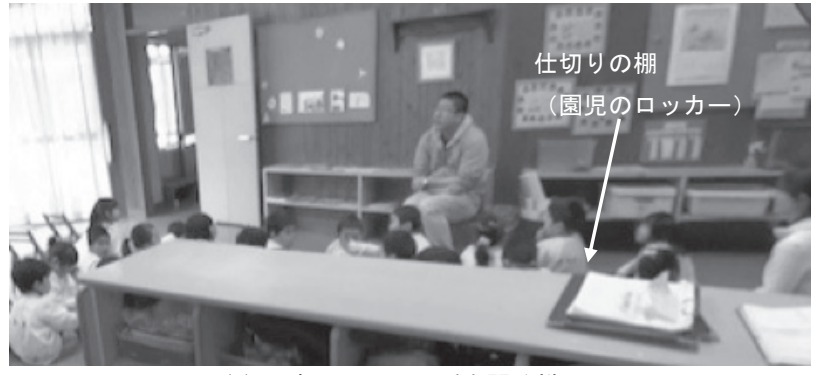

(c) 3 歳スペースで話を聞く様子

図 $7 \quad K$ 園における連続した空間での活動場面

められる環境、午睡時の睡眠環境としての音環境を保全する必要が ある。学校施設における室内騒音レベルの推奨值 ${ }^{8)}$ は、普通教室で $40 \mathrm{~dB}$ 、聴覚障害をもつ児童が言語訓練を行うための難聴学級教室で $35 \mathrm{~dB}$ であるが、今回の調査では、活動に伴う発生音がほぼない午 睡時の音環境でもこれらの值を上回る測定結果であった。高架下で 電車の通過音がはっきり確認できるケースや、終日稼働している機 械換気設備・空調設備による騒音が高いケースが確認されたが、保 育施設は立地に対する自由度が高いため、騒音源が近接しているケ 一スや、壁や床を隔てて他の用途施設が隣接するケースもあると考 えられ、これらの騒音の防止策に対して、注意喚起が必要と考えら れる。また、午睡や読み聞かせなどを行う室は特に静けさを保つこ とが望ましい室と考えられ、部屋の用途や活動に応じた室内騒音の 推奨值を示すことも必要と考えられる。午睡をとる室では、床振動 に対する配慮も求められる。

\section{2 遮音性能 \\ （1）室間の遮音性能}

保育室内における発生音は、同時多発的に音声・物音・楽器音が 発生する場面も多く、低年齢児ではこれに欲求や不安を訴える泣 き・叫びという発声行動も加わる。図 5 に示した測定結果は、学校 の音の発生状況 ${ }^{8)}$ としては特別教室（60〜80 dB，最大 $85 \mathrm{~dB} ）$ と同 程度の結果であった。普通教室（発生音は $50 \sim 70 \mathrm{~dB}$, 最大 $80 \mathrm{~dB}$ 程 度）よりは大きい結果であるが、既往の研究 14) 16)でも、65 $85 \mathrm{~dB}$ 
程度の結果が多く報告されている。このことから、保育室間で異な る活動を互いに妨害し合うことなく行うためには、学校の特別教室 間と同程度の遮音性能が必要と考えられる。一方で、異年齢保育の 導入や運用上の利点を狙って柔軟なスペース利用を図る場合や、小 規模な保育所の場合などでは、年齢ごとに保育室を分けずに、連続 した一体空間を柵や棚、カーテン、建具などによって分割するケー スも多くみられた。上述の遮音性能を簡易的な仕切りによって確保 することは不可能であり、少なくとも乳児の午睡スペースと幼児が 活動するスペースは別室とする、異年齢保育を行わない保育室間は 一体空間としないなど、保育時の空間の用途に応じて遮音性能の面 からスペースの区画分けを考える必要がある。

学校施設では、オープンプラン型の教室がしばしば導入されてい るが、必要遮音性能を確保することはまず不可能であることから、 吸音仕上げや可動間仕切りの設置など建築上の対策と合わせて、運 用段階の配慮が不可欠となっている。オープン型（一体空間型）保 育室の音環境については、オープンプラン教室における対策事例な ども参考に、今後も改善手法などの検討が必要と考えられる。

近年では、保育施設から発生する音が近隣への騒音源として問題 視されることも多く、立地によっては外周壁の遮音性能の確保につ いても慎重な配慮が求められる。

\section{（2）床衝撃音遮断性能}

午睡という保育施設特有の行為があり、午睡時には床に直接薄手 のマットや布団を敷くケースが多くみられた（表４）ことから、外 部からの床衝撃や床振動の遮断性能の確保には特に注意が必要と考 えられる。保育室が積層していた園ではいずれも上階に幼児室、下 階に乳児室が配置されており、この場合、上階での幼児の活動に伴 って発生する床衝撃が下階の乳児の午睡環境に影響する懸念がある。 また、上下階に異なる用途の施設が隣接する場合もあるため、それ らの音環境上の要請も把握して床衝撃音の防止を図る必要がある。 保育室での主な床衝撃源としては素足の子じもの足音であり、これ は学校の教室で想定されている床衝撃とは異なるため、実測データ などをもとに推奨值を検討寸ることも必要と考えられる。なお、八 ンモック型の簡易ベッド（図 2 (f) ) が一部の園で使われており、こ れは床衝撃や床振動に対して有効な対策といえる。

\section{3 室内の響き}

保育室では、言語や聴力の発達段階の乳幼児に音声が明瞭に聞き 取れる環境を与えるという観点から、学校の普通教室と同様に中庸 の響き、あるいは一ランク高い難聴学級教室と同等の短めの響きを 確保す心゙きと考えられる ${ }^{3)}$ 。いずれにしても天井面等に吸音材を使 用寸る必要があるが、今回の調查対象園のうち、保育室内に吸音材 が使われていた園は $1 / 4$ であり、保育室の設計時に響きについて配 慮されることは少ない現状が確認された。響きの影響が顕著になり やすい事例としては、一体空間型の保育室など広い空間を仕切らず に使用する場合、平屋建てで天井が高い保育室・遊戯室が確認され、 このようなケースでは音声明瞭度の低下とともに喧噪感の増大が起 こり、児童への影響とともに保育士の疲労感の増大や発声障害の原 因となることに注意喚起が必要である。後付けの吸音材設置方法や その効果について検証した事例も報告されており 17)-20)、今後保育現 場に普及を促す取組みが望まれる。

\section{5. むすび}

近年開設した保育施設の実態調查より、特に空間の仕切り方とそ の背景となる考え方、室内の静けさの確保において留意すべきケー ス、室の響きに関わる現状や使用者の意見について報告した。小学 校などの学校施設と比べても、空間構成や保育環境に関する考え方 には大きな差があることが確認された。今後は、このような現状を 踏まえ、また学校以上に心身・各種能力が未熟な子どもたちの居場 所として落着きや安らぎ、安心感を得られる生育環境のあり方を問 いながら、保育施設の音環境保全指針の作成や設計・運用を支援し ていくことが必要と考える。

\section{謝辞}

実態調査にご協力いただいた保育園関係者、実施及びまとめにあ たった明治大学 (当時) 三浦吉博氏、石田久美子氏、梅澤里恵氏に 謝意を表します。本研究は J S P S 科研費 25350947 の助成を受けた。

\section{参考文献}

1) 荒井隆行，麦倉綾子：子供を取り巻く音環境と音声言語に関わる発達につ いて, 日本音響学会誌 72 巻 3 号, pp.129-136, 2016.3.

2) 白石君男: 子供の聴覚発達と音環境, 日本音響学会誌 72 巻 3 号, pp.137-143, 2016.3 .

3) 川井敬二 : 保育空間の音環境の現状、現存する海外の設計基準，日本建築 学会第 75 回音シンポジウム資料, pp.6-11, 2015.7.

4)松井利仁: 交通騒音による子どもへの健康影響, 騒音制御,38 巻 pp. 197-200, 2014

5) L.Grebennikov: Preschool teachers' exposure to classroom noise, Intl. J. Early Years Education 14(1), pp.35-44, 2007

6) K.P. Waye et.al: Being in a pre-school sound environment - annoyance and subjective symptoms among personnel and children, Proceedings of Inter-noise 2010

7) 志村洋子: 保育活動と保育室内の音環境一音声コミュニケーションをはぐ くむ空間をめざして, 日本音響学会誌 72 巻 3 号, pp.144-151, 2016.3

8）日本建築学会:学校施設の音環境保全規準・設計指針, 2008 .

9)吉澤玲児，井上勝夫，冨田隆太：保育園の音環境の現状と保育士の意識, 日本騒音制御工学会講演論文集, pp.9-12, 2012.9

10) 佐藤将之: 地域資源となり得る保育建築とは, 新建築, 第 91 巻 9 号 pp. $38-41$, 2016.5 .

11) 豊田恵美, 杉江聡，吉村純一:折り紙インパルス音源の音響特性：残響時 間測定一の適用，日本音響学会建築音響研究会資料 AA2008-68，2008.12.

12) 若盛正城：こどものもりの保育実践を踏まえて, エデュケア 21 , 別冊最 終総括号, pp.7-9，2015.2.

13) 武岡紗生, 宮塚健, 上野佳奈子 : 低年齢児保育場面での発声行動の調查 一子ども・保育者のかかわりに着目して一, 日本音響学会騒音振動研究会 資料 N2015-45，2015.08.

14) 志村洋子：幼稚園・保育所における保育室内の音環境一コミュニケーシ ヨンを支える音環境一，騒音制御，Vol.27，No.2，pp.123-127，2003.4.

15) 野口紗生, 小西雅, 及川靖広, 山㠃芳男 : 幼児の学習活動に着目した一 斎保育活動場面における音環境の把握, 日本建築学会計画系論文集, Vol.77, No.672, pp.301-307, 2012.2.

16) 野口紗生，小西雅：子ども・保育者とあそび空間とのかかわりに着目し た自由保育場面の音環境調査, 日本建築学会計画系論文集, Vol.80, No.718, pp.2771-2779, 2015.12 .

17) 川井敬二：保育空間における喧噪な音環境に対する室内吸音の効果の検 証, こども環境学研究, Vol.8, No.2, 58-64, 2012

18) 大和田千聖, 船場ひさお : 保育園における音環境向上に向けた現場実験, INCE/J 講演論文集，81-82，2013.9

19）三浦吉博，石田久美子，上野佳奈子，大和田千聖，船場ひさお，川井敬 二：保育室における吸音材設置の効果に関する現場実験，日本音響学会講 演論文集，pp.1203-1206，2014.3. 
20) 宮塚健, 武岡紗生, 上野佳奈子：保育空間に適した吸音材設置手法の検 討, 日本音響学会騷音振動研究会資料 N2015-44，2015.08.

注

注 1）音環境の測定は、特別な行事のない通常保育日 1 日に実施し、保育活 動に伴う音の発生状況を知ること、保育士・览童が暴露されている音環境 を知ることを目的とした。測定機材は、活動場所の近傍かつ保育活動の妨 害にならない場所として、室内の棚の上などに設置した。

注 2 ) 天井面の線が分断している箇所は、間に空間（別室）があるか、別の 階であることを示している。K園は、保育園棟（主に0 2 歳児が利用）と 幼稚園棟（3〜 5 歳児）の 2 棟から成るが、 3 歳児は両方の棟を利用してい る。また、 0,1 歳児は、活動時は同じスペースを使用するため図 1 上では同 室と表記しているが、午睡時は別室（0 歳 : ベビーベッド、 1 歳 : 和室 $)$ を 用いている。

注 3 ) $\mathrm{I} ・ \mathrm{~K}$ 園については複数の年齢の活動の測定結果を示しており、プロッ 卜横の文字は測定対象の年齢を示している。

注 4）平均吸音率 $\bar{\alpha}$ は、 $1 \mathrm{kHz}$ 帯域の残響時間測定結果から計算した值を示寸。 


\title{
A FIELD STUDY OF NURSERY FACILITIES FOCUSING ON SOUND ENVIRONMENT
}

\author{
Kanako UENO ${ }^{* 1}$, Ken MIYATSUKA ${ }^{* 2}$, Saki NOGUCHI ${ }^{* 3}$, \\ Hisao FUNABA *4 and Ryoko KURAKAZU ${ }^{* 5}$ \\ ${ }^{* 1}$ Prof., School of Science and Technology, Meiji Univ., Dr.Eng. \\ *2 Grad. Stud., Graduate School of Science and Technology, Meiji Univ. \\ *3 Post-doctoral Research Fellow, OSRI, Meiji Univ., Dr.GITS \\ ${ }^{*}$ Assoc. Prof., Center of Community Promotion Office, Iwate Univ., Dr.Design \\ ${ }^{* 5}$ Assoc. Prof., Dept. of Design, Faculty of Creative Eng., Chiba Institute of Technology, Dr.Eng.
}

A conducive acoustical environment for children is considered essential to support healthy growth. However, the significance of acoustical quality in nursery facilities has not been fully recognized in building design. Further, the management and types of nursery schools are now diversifying and various acoustic disturbances such as excessive noise in the environment or reverberation are often noticed. At present, the architectural Institute of Japan (AIJ) indicates the guidelines for acoustical properties of schoolrooms for elementary schools, as well as junior and senior high schools. AIJ is also working to extend the guideline for schoolrooms to nursery facilities and preschools. Against this background, the study conducted a field survey across twelve nursery facilities to assess the status of acoustical environment.

The survey observed the division of spaces for each age, the dimensions of and finish on surfaces in rooms, and children's activities conducted within them. Additional information was collected on the background and characteristics of each facility, the users' evaluation of facilities, and evaluation of the acoustical environment in nursery rooms. Noise levels and reverberation time were measured in four facilities, and a management system to maintain a comfortable sound environment was observed in one facility.

The survey on the division of spaces for each age group indicated that in most facilities, the nursery rooms were designed with poor acoustical separation. A typical case of successive nursery spaces was observed in a rented room in a part of the building. Here, the successive spaces were divided by low shelfs or fences, and groups of different ages engaging in different activities shared the sound environment. Additionally, some nurseries were characterized by mixed-age grouping activities and spaces were set not by ages but by activities. Movable partitions and sliding doors were installed to ensure flexible use of spaces according to the activities. Connectivity between spaces was found to facilitate cooperation, but was detrimental to the sound environment. As observed in the survey, such "mono-spaces"- connected rooms without sufficient sound insulation-may cause acoustical problems. As some teachers mentioned during their interviews, there were instances of acoustical disturbance due to voices from other groups.

The survey found sound-absorptive materials in use in only a few of the facilities visited. Long reverberation times were measured in nursery rooms without absorptive materials, especially those with a high ceiling and those organized as successive spaces. Another typical problem was noise exposure attributable to the ventilation system and site location such as underneath elevated railway tracks. In nursery facilities, the effects of noise should be considered not only in the context of speech communication, but also in the context of sleep disturbance during naptime.

It was observed that a management method to maintain a comfortable sound environment was important. In one nursery facility, nurses pursue the concept of "break away from the noise" and participate in a training session every year. The facility also inculcates practices of gentle vocal communication, and measurements showed lower levels of sound generation during activities.

The results of this study indicate considerable differences between the acoustical environments in nursery facilities and school buildings. It is hoped that the findings of this study will be taken into consideration while formulating guidelines for acoustical environments in nursery facilities. It is also necessary to diversify the method to improve acoustical environment through additional absorptive treatment and effective management to maintain a comfortable sound environment. 